\title{
Measuring the Vocabulary Burden of Popular English Songs
}

\author{
Rick Romanko \\ Wayo Women's University \\ doi: http://dx.doi.org/10.7820/vli.v06.2.Romanko
}

\begin{abstract}
This study measured the vocabulary burden of popular English songs to determine what vocabulary is needed to understand $95 \%$ and $98 \%$ of the words in songs. The researcher analyzed the vocabulary in 2,175 songs, which consisted of 678,309 tokens. The results showed that knowledge of the most frequent 2,000 word families and proper nouns and marginal words provided $96.05 \%$ coverage, and knowledge of the most frequent 5,000 word families and proper nouns and marginal words provided $98 \%$ coverage of the English used in songs in the corpus.
\end{abstract}

\section{Introduction}

It is well recognized that input for second-language learners needs to be comprehensible. There is also agreement that the use of comprehensible authentic materials benefits the learning process (e.g., Guariento \& Morley, 2001). Educators have been using songs as input of this type for English language learning for many years. The L2 pedagogical literature is replete with descriptions and testimonies of useful classroom activities using music and songs (e.g., Brand, 2007; Domoney \& Harris, 1993; Lems, 2005). However, the lexical demands of English songs can pose problems for L2 learners who lack the appropriate level of receptive vocabulary knowledge necessary to sufficiently comprehend them. Thus, it is important to establish the level of vocabulary needed to effectively facilitate comprehension of popular English songs.

\section{Lexical Profiling}

The idea behind lexical profiling research is the principle that the more frequent a word is, the more important it is to learn and the more likely it is to be learnt (Milton, 2009; Nation, 2013a). This line of research has provided educators with an extremely useful set of resources that they can apply to curriculum and course design, the setting of learning goals, materials development, and vocabulary analysis and test development (Nation \& Webb, 2011). As Brown (2013) explained, lexical profiling research consists of three strands: (1) generating word lists based on the frequency of occurrence and range of use in large corpora, (2) examining text coverage, the number of words needed to make up a certain percentage of a text, and (3) measuring the amount of coverage, the percentage of known words in a text, required for successful comprehension of a text. The second 
strand, examining text coverage, can be used to measure the vocabulary burden of popular English songs in order to determine what vocabulary level is necessary to adequately comprehend songs.

\section{Research on Text Coverage}

The primary goal of text coverage studies is to determine the percentage of word families at various frequency levels in written or spoken texts. By doing so, researchers can calculate the probabilistic vocabulary thresholds that learners need to reach in order to have a greater likelihood of comprehending a certain type of discourse. Two key thresholds commonly presented in research studies of this type are the number of word families needed for $95 \%$ and $98 \%$ coverage of a text. Basically, the lower boundary of $95 \%$ represents minimal to reasonable comprehension for written texts (Laufer \& Ravenhorst-Kalovski, 2010) and good, but not necessary complete comprehension for spoken discourse (Bonk, 2000; Van Zeeland \& Schmitt, 2013) while the upper boundary of 98\% represents adequate, unassisted to optimal comprehension for written texts (Hu \& Nation, 2000; Schmitt, Jiang, \& Grabe, 2011), and very high comprehension for spoken discourse (Van Zeeland \& Schmitt, 2013).

Studies examining written discourse (e.g., Nation, 2006) have found that in most cases approximately the first 4,000 word families plus proper nouns and marginal words (PNAMW) typically provide 95\% coverage, while the first 8,000 word families plus PNAMW typically provide $98 \%$ coverage. Studies examining spoken discourse (e.g., Webb \& Rodgers, 2009a, 2009b) have reported that in most cases, roughly the first 3,000 word families and PNAMW typically provide $95 \%$ coverage, while the first 7,000 word families and PNAMW typically provide $98 \%$ coverage.

\section{Purpose of This Study}

There have been only two small-scale academic studies which have examined the vocabulary of songs. Murphey (1992) analyzed a 13,000 word corpus of the top 50 songs in English from the September 12, 1987 Music \& Media Hot 100 Singles chart and Meara (1993) did a lexical analysis of the roughly 1,500 words that made up the pop songs of British-Irish singer-songwriter Chris de Burgh's album Into the Light (de Burgh, 1986). An investigation which examines the lexical challenges or popular English songs with a larger, more comprehensive corpus would now be informative. The aim of this article is to contribute to the growing body of lexical profiling research and report on one of the main findings from a larger research project that answered the following research question:

What vocabulary size, in terms of knowledge of word-frequency levels, is necessary to reach $95 \%$ and $98 \%$ coverage of popular English songs?

Since there has not been any investigation of the coverage levels needed for the comprehension of songs, the coverage levels borne out in the text coverage research for spoken and written discourse have been adopted here. 


\section{Method}

\subsection{Materials}

The 678,309-token song corpus used in this study consisted of 2,175 songs. The average number of tokens (words) per song was 312 . The goal was to provide an accurate representation of commonly listened to songs by creating a corpus representative of well-known songs from a variety of genres. This was done by selecting songs based on their impact and influence on culture from the 1950s through to the 2000s. A song's impact on culture was determined by: (1) a song's ranking by experts in the music industries in the United States (US) and the United Kingdom (UK) and (2) a song's popularity based on radio airplay, sales data, and streaming data in the US, and sales and streaming data in the UK.

Songs based on music industry expert opinion were taken from the best of song lists published by two established music magazines - Rolling Stone magazine in the US and New Musical Express in the UK. A total of 885 of the 1,100 songs from the Rolling Stone and New Musical Express best of song lists were used in the corpus. There were 207 songs that appeared on more than one list, two foreign language songs, five instrumental songs and one song released before the 1950 s that were not entered into the corpus.

For a song to be selected based on its popularity, it had to reach the number one position in the Billboard Magazine's Billboard Hot 100 Chart in the US or the Official Charts Company's UK Singles Chart in the UK. The rationale is that these songs are arguably the most popular, the most familiar and listened to by a wide audience, and have/had the greatest cultural impact. A total of 1,290 number one songs from the music charts in the US and UK from January 1950 to December 2009 were collected for the corpus. This accounted for nearly $60 \%$ of all the number one songs from the two charts during this period. Instrumental songs, foreign language songs, and spoken comedy tracks from the charts were not included in the corpus. Songs that reached the number one position in both charts were only entered into the corpus once.

Text files of all of the song lyrics were created and used for the analysis. Nonsense words, unintelligible words and phrases that could not be heard clearly in the songs, and foreign language words used in the lyrics were removed from the corpus. This accounted for $0.23 \%$ of the corpus. The spellings of words said as connected speech such as wanna for want to or want a and lemme for let me, and reduced speech such as rockin' for rocking, 'em for them or him and $a$ ' or $n$ for the word and were changed to conform to the spellings used in the BNC/COCA wordlists, which were used for the analysis. Each occurrence of connected speech and/or reduced speech was confirmed by listening to each song in the corpus. When connected speech and/or reduced speech had not been transcribed in the lyrics, it was added to the text files. Connected and reduced speech accounted for 3.3\% of the tokens in the corpus. Webb and Rodgers (2009a, 2009b) suggested that the amount of connected and reduced speech in spoken English may be one of a number of factors which influence comprehension and vocabulary learning. It should be noted that knowing the full forms of the words does not guarantee 
that listeners will be able to recognize the reduced forms or connected speech in the songs.

\subsection{Analysis}

The AntWordProfiler program (Anthony, 2014) was used to analyze the song lyrics in the corpus. This program generates vocabulary statistics and frequency information about a corpus of texts analyzed with the software. It compares the words in a corpus against a set of vocabulary level lists that are used with it.

To find the vocabulary size necessary to reach $95 \%$ and $98 \%$ coverage of songs in the corpus, Nation's (2012) 25 1,000-word BNC/COCA frequency lists were used with AntWordProfiler to show in which 1,000 word family level $(1,000-25,000)$ the words in the songs occurred. The BNC/COCA lists use word families as the unit of counting, which Nation (Nation, 2013b, 2016) and Nation and Webb (2011) consider to be a sensible unit of counting for receptive purposes like listening and reading, the two ways song lyrics are received (cf. Brezina \& Gablasova, 2015; Brown, 2013; Gardner \& Davies, 2014). Moreover, since the lists inherit the strengths and weaknesses of the corpora they are derived from, the BNC/COCA word family lists, developed with both spoken and written, British and American discourse, were considered most appropriate for the unique nature of the majority of songs in this corpus, which were written and sung by both American and British artists. The word families in the lists were based on Bauer and Nation's (1993) Level 6 classification of word families. Level 6 word families include inflections and all of the derivational affixes (91) from Levels 2-6. For more information about the word lists see Nation $(2012,2016)$. Proper nouns and marginal words (e.g., woh, shooby, and aaow) which appeared in the "not in the lists" category (words less frequent than the most frequent 25,000 word families and not found in any of the supplementary word lists used in the analysis) were reclassified as proper nouns and marginal words and added to those supplementary lists.

\section{Results}

Table 1 presents the tokens, types, and cumulative coverage with and without PNAMW for the 2,175 popular English song corpus. In column seven, PNAMW were added to the coverage figures needed to know each 1,000 word level as they have a lower learning burden than regular words and learners with a reasonable vocabulary are likely to know or be able to recognize them (Nation \& Webb, 2011) (cf. Brown, 2010).

The bottom row shows that there was a total of 678,309 tokens, 12,342 different word types, and 7,794 word families contained in the corpus. Most of the tokens in the corpus were accounted for by the first 1,000 word families $(582,309)$. These tokens represented $85.85 \%$ of the total tokens in the corpus. This shows the importance of knowing the most frequent word families in English. The figure $92.98 \%$ in the top cell in Column 7 is the coverage of the most frequent 1,000 word families $(85.85 \%)$ plus the coverage of PNAMW (1.09 and 6.04\%, respectively). The second highest percentage of words in the corpus after the first 1,000 word families was for marginal words (6.04\%). Compared to the percentage of marginal words in previous corpus studies on movies $(0.70 \%)$ and TV $(1.03 \%)$ (Webb \& Rodgers, 2009a, 2009b) marginal words seem to be a distinctive feature of the vocabulary used in songs. Evidence of this can be seen in the 
Table 1. Tokens, Types, and Cumulative Coverage with and Without Proper Nouns and Marginal Words for 2,175 Songs

\begin{tabular}{|c|c|c|c|c|c|c|}
\hline Word list & Tokens & Token (\%) & Types & $\begin{array}{c}\text { Word } \\
\text { families }\end{array}$ & $\begin{array}{c}\text { Coverage } \\
\text { without } \\
\text { PNAMW (\%) }\end{array}$ & $\begin{array}{c}\text { Coverage } \\
\text { including } \\
\text { PNAMW (\%) }\end{array}$ \\
\hline 1,000 & 582,309 & 85.85 & 2977 & 996 & 85.85 & 92.98 \\
\hline 2,000 & 20,795 & 3.07 & 1927 & 907 & 88.92 & $96.05^{\star}$ \\
\hline 3,000 & 4,871 & 0.72 & 1003 & 628 & 89.64 & 96.77 \\
\hline 4,000 & 5,261 & 0.78 & 956 & 582 & 90.42 & 97.55 \\
\hline 5,000 & 3,072 & 0.45 & 719 & 504 & 90.87 & $98.00^{+}$ \\
\hline 6,000 & 2,633 & 0.39 & 543 & 403 & 91.26 & 98.39 \\
\hline 7,000 & 1,480 & 0.22 & 378 & 308 & 91.48 & 98.61 \\
\hline 8,000 & 1,151 & 0.17 & 284 & 236 & 91.65 & 98.78 \\
\hline 9,000 & 1,003 & 0.15 & 241 & 199 & 91.80 & 98.93 \\
\hline 10,000 & 604 & 0.09 & 178 & 159 & 91.89 & 99.02 \\
\hline 11,000 & 619 & 0.09 & 130 & 118 & 91.98 & 99.11 \\
\hline 12,000 & 591 & 0.09 & 125 & 112 & 92.07 & 99.20 \\
\hline 13,000 & 421 & 0.06 & 98 & 87 & 92.13 & 99.26 \\
\hline 14,000 & 270 & 0.04 & 61 & 59 & 92.17 & 99.30 \\
\hline 15,000 & 267 & 0.04 & 58 & 54 & 92.21 & 99.34 \\
\hline 16,000 & 212 & 0.03 & 47 & 46 & 92.24 & 99.37 \\
\hline 17,000 & 72 & 0.01 & 31 & 31 & 92.25 & 99.38 \\
\hline 18,000 & 103 & 0.02 & 33 & 32 & 92.27 & 99.40 \\
\hline 19,000 & 46 & 0.01 & 22 & 22 & 92.28 & 99.41 \\
\hline 20,000 & 55 & 0.01 & 23 & 22 & 92.29 & 99.42 \\
\hline 21,000 & 47 & 0.01 & 16 & 15 & 92.30 & 99.43 \\
\hline 22,000 & 37 & 0.01 & 8 & 8 & 92.31 & 99.44 \\
\hline 23,000 & 135 & 0.02 & 21 & 17 & 92.33 & 99.46 \\
\hline 24,000 & 97 & 0.01 & 8 & 8 & 92.34 & 99.47 \\
\hline 25,000 & 5 & 0.00 & 5 & 5 & 92.34 & 99.47 \\
\hline Compounds & 2,362 & 0.35 & 405 & 363 & 92.69 & 99.82 \\
\hline Acronyms & 294 & 0.04 & 65 & 62 & 92.73 & 99.86 \\
\hline Slang & 631 & 0.09 & 111 & 95 & 92.82 & 99.95 \\
\hline Proper nouns & 7,396 & 1.09 & 1,405 & 1363 & 93.91 & \\
\hline Marginal words & 40,982 & 6.04 & 245 & 134 & $99.95+$ & \\
\hline Not in the lists & 488 & 0.07 & 219 & 219 & 100.02 & 100.02 \\
\hline Total & 678,309 & & 12,342 & 7,794 & & \\
\hline
\end{tabular}

Note: Based on the BNC/COCA word family lists.

PNAMW $=$ proper nouns and marginal words .

${ }^{*}$ Reaching $95 \%$ coverage. ${ }^{+}$Reaching $98 \%$ coverage.

most frequent 100 word types. Nine of the most frequent 100 word types in the corpus were marginal words. They were, oh $(6,302$ occurrences), doo $(4,182)$, lah $(3,432)$, ooo (2,091), ooh (2,051), nah (1,791), bah (1,431) dah (1,405), and ah (1,325).

The results indicated that knowledge of the most frequent 2,000 English word families and PNAMW is needed to reach 95\% coverage $(96.05 \%)$, while knowledge of the most frequent 5,000 English word families plus PNAMW is required to reach $98 \%$ coverage $(98 \%)$. 


\section{Discussion}

In answer to the research question, a vocabulary size of the 2,000 most frequent word families and PNAMW is required to reach $95 \%$ coverage, while a vocabulary size of the most frequent 5,000 word families plus PNAMW is necessary to reach $98 \%$ coverage. This is in agreement with the results of previous studies of general spoken English which showed a vocabulary size of around 3,000 word families plus PNAMW is needed for $95 \%$ coverage, while a vocabulary size of roughly 7,000 word families plus PNAMW is required for $98 \%$ coverage. These findings suggest that if $95 \%$ coverage is adequate for comprehension then songs may be an appropriate source of input for English-language learners (ELL). Learning the 2,000 most frequent word families of English would be an achievable goal for many ELL. However, if $98 \%$ coverage is required for comprehension then songs may be more useful for intermediate and advanced learners who already have a substantial vocabulary. Learning the most frequent 5,000 word families would be a challenging goal that many ELL may fall short of without concerted effort. It should be noted that the levels of coverage that have been found necessary/and or adequate for coverage of spoken and written texts may not be the same for songs.

With regard to PNAMW in songs, although some marginal words may need to be learned by some learners (Nation, 2016), the marginal words used in songs should pose a minimal burden as they are predominantly interjections, exclamations, and nonsense syllables used to express emotions and make sounds that flow with the music. For example, six of the nine marginal word types in the top 100 word types in the corpus (doo, lah, ooo, nah, bah, and dah) were non-lexical vocables, syllables without lexical or semantic content (Chambers, 1980) that are used to sing the melody and/or rhythm of a song instead of regular words. The more learners use English songs for learning purposes, the more likely they will become familiar with the way these types of marginal words are used in songs. On the other hand, the percentage of proper nouns found in songs $(1.09 \%)$, while significantly less than in previous corpus studies on movies $(2.67 \%)$ and TV $(2.96 \%)$ (Webb \& Rodgers, 2009a, 2009b), may still be challenging for some learners. Research shows that proper names that require previous knowledge are potential comprehension barriers that need to be taken into consideration (Kobeleva, 2012). For example, Lebron (an American professional basketball player), which appeared in the song corpus, would likely require learning in much the same way as other words for many ELL unfamiliar with this American sports star, especially in listening-only situations where its form (an initial capital letter) cannot be used to help recognition and/or comprehension.

\section{Conclusion}

This report on one of the main findings from a larger research project has shown that to reach 95\% coverage of the spoken (sung) English used in popular English songs, ELL require knowledge of the most frequent 2,000 English word families and PNAMW. This suggests that songs have the potential to be accessible language and vocabulary leaning resources for a wide range of language learners. However, it is important to note that knowledge of the most frequent 2,000 word families and PNAMW does not guarantee adequate comprehension. As well, 
teachers and ELL need to keep in mind that the vocabulary burden will vary between songs, which emphasizes the importance of using lexical profiling to find songs that best suit their language and vocabulary learning needs.

\section{References}

Anthony, L. (2014). AntWordProfiler (Version 1.4.1) [Computer Software]. Tokyo, Japan: Waseda University. Retrieved from http://www.laurenceanthony.net/

Bauer, L., \& Nation, P. (1993). Word families. International Journal of Lexicography, 6(4), 253-279. doi:10.1093/ij1/6.4.253

Bonk, W.J. (2000). Second language lexical knowledge and listening comprehension. International Journal of Listening, 14(1), 14-31. doi:10.1080/10904018.2 000.10499033

Brand, M. (2007). Music, Asia, and English: Use of pop songs in ESL instruction. Asia-Pacific Journal for Arts Education, 5(2), 66-75.

Brezina, V., \& Gablasova, D. (2015). Is there a core general vocabulary? Introducing the new general service list. Applied Linguistics. 36(1), 1-22. doi:10.1093/ applin/amt018

Brown, D. (2010). An improper assumption? The treatment of proper nouns in text coverage counts. Reading in a Foreign Language, 22(2), 355-361.

Brown, D. (2013). Types of words indentified as unknown by L2 learners when reading. System, 41, 1043-1055. doi:10.1016/j.system.2013.10.013

Chambers, C.K. (1980). Non-lexical vocables in Scottish traditional music. Unpublished doctoral thesis, University of Edinburgh, Edinburgh, Scotland.

de Burgh, C. (1986). Into the light. London, England: A\&M.

Domoney, L., \& Harris, S. (1993). Justified and ancient: pop music in EFL classrooms. ELT Journal, 47(3), 234-241. doi:10.1093/elt/47.3.234

Gardner, D., \& Davies, M. (2014). A new academic vocabulary list. Applied Linguistics, 35(3), 305-327. doi:10.1093/applin/amt015

Guariento, W., \& Morley, J. (2001). Text and task authenticity in the EFL classroom. ELT Journal, 55(4), 347-353. doi:10.1093/elt/55.4.347

$\mathrm{Hu}$, M., \& Nation, I.S.P. (2000). Vocabulary density and reading comprehension. Reading in a Foreign Language, 13(1), 403-430. Retrieved from http://nflrc. hawaii.edu/rfl/PastIssues/rfl131hsuehchao.pdf

Kobeleva, P.P. (2012). Second language listening and unfamiliar proper names: Comprehension barrier? RELC Journal, 43(1), 83-98. doi:10.1177/0033688212440637

Laufer, B., \& Ravenhorst-Kalovski, G.C. (2010). Lexical threshold revisited: Lexical text coverage, learners' vocabulary size and reading comprehension. Reading in a Foreign Language, 22(1), 15-30.

Lems, K. (2005). Music works: Music for adult English language learners. New Directions for Adult \& Continuing Education, 107, 13-21.

Meara, P. (1993). Tintin and the World Service: A look at lexical environments. Hornby Trust Lecture, IATEFL Annual Conference Report (pp. 32-37). Swansea. 
Milton, J. (2009). Measuring second language vocabulary. Bristol, UK: Multilingual Matters.

Murphey, T. (1992). The discourse of pop songs. TESOL Quarterly, 26(4), 770-774. doi: $10.2307 / 3586887$

Nation, I.S.P. (2006). How large a vocabulary in needed for reading and listening? Canadian Modern Language Review, 63(1), 59-82. doi:10.1353/cml.2006.0049

Nation, I.S.P. (2012). Notes on the BNC/COCA lists. Wellington, New Zealand: Victoria University of Wellington. Retrieved from http://www.victoria. ac.nz/lals/about/staff/paul-nation

Nation, I.S.P. (2013a). Learning vocabulary in another language (2nd ed.). Cambridge, UK: Cambridge University Press.

Nation, I.S.P. (2013b). Vocabulary acquisition in second language acquisition. In C. A. Chapelle (Ed.), The encyclopedia of applied linguistics. Oxford, UK: Wiley-Blackwell.

Nation, I.S.P. (2016). Making and using word lists for language learning and testing. Amsterdam: John Benjamins.

Nation, I.S.P., \& Webb, S. (2011). Researching and analyzing vocabulary. Singapore: Cengage Learning.

Schmitt, N., Jiang, X., \& Grabe, W. (2011). The percentage of words known in a text and reading comprehension. The Modern Language Journal, 95(1), 26-43. doi: 10.1111/j.1540-4781.2011.01146.x

van Zeeland, H., \& Schmitt, N. (2013). Incidental vocabulary acquisition through L2 listening: A dimensions approach. System, 41(3), 609-624. doi:10.1016/j. system.2013.07.012

Webb, S., \& Rodgers, M. (2009a). The lexical coverage of movies. Applied Linguistics, 30(3), 407-427. doi: 10.1093/applin/amp010

Webb, S., \& Rodgers, M. (2009b). The vocabulary demands of television programs. Language Learning, 59(2), 335-366. doi: 10.1111/j.1467-9922.2009.00509.x 